\title{
PROTECTION OF ARCHAEOLOGICAL REMAINS IN THE YORTANLI DAM RESERVOIR IN TURKEY
}

\author{
Mine Hamamcioglu-Turan, ${ }^{1}$ Yalcin Arisoy, ${ }^{2}$ Ayhan Nuhoglu, ${ }^{3}$ \\ and Yusuf Percin Erturan ${ }^{4}$ \\ ${ }^{1}$ Department of Architectural Restoration, Izmir Institute of Technology, Izmir, \\ Turkey \\ ${ }^{2}$ Department of Civil Engineering, Dokuz Eylul University, Izmir, Turkey \\ ${ }^{3}$ Department of Civil Engineering, Ege University, Izmir, Turkey \\ ${ }^{4}$ Department of Architecture, Dokuz, Eylul University, Izmir, Turkey
}

This study discussed conflicts in a large-scale development project realized in an archaeological area. The dam reservoir of Yortanli constructed as a part of a contemporary irrigation project in Western Turkey conflicted with the antique settlement of Allianoi, which had developed in the same area around a natural thermal spring in the 2nd century ad. The aim was to present the protection decisions and implementations related with the archaeological site of Allianoi in the Yortanl Dam Reservoir so that monitoring and criticism of its consequences can be possible in the future. The tools of the three disciplines, hydraulic engineering, structural engineering and conservation, were emphasized. The following conclusions were derived: The understanding of the protection-development conflict of archaeological heritage-dam relations in the case of Allianoi-Yortanl necessitates the evaluation of its legal, administrative, technical, and managerial aspects with all related governmental and nongovernmental parts. The presented evaluation provides an opportunity for the discussion of the validity of the protection intervention, which is reburial of the remains prior to water retention in the dam, within an international framework. The presentation of the details of the protection process may facilitate the monitoring and criticism of its consequences in the future.

KEY WORDS: archaeological heritage, dam, protection, development, Turkey

\section{INTRODUCTION}

Protection of cultural heritage requires social development as revealed in the amount of public participation and enthusiasm in conservation matters as an outcome of taking responsibility in the decision-making process (ICOMOS 1990; Serin 2005). It also requires economic development as pointed out in the related international documents: Conservation should be an integral part of coherent policies of economic and social development and planning (ICOMOS 1987; 1990). The cultural heritage of developing countries with limited budgets are confronted with relatively more risk and threats compared with those of the developed ones including rapid development and insufficient preservation know-how (ICOMOS 2010). In turn, establishment of a protection-development balance in accordance

Received September 14, 2011; accepted January 4, 2012.

Address correspondence to Mine Hamamcioglu-Turan, Izmir Yuksek Teknoloji Enstitusu, Mimari Restorasyon Bol., 35430 Urla, Izmir, Turkey. E-mail: mineturan@iyte.edu.tr 
with the legal, administrative, technical, and managerial infrastructure of each country is important.

Turkey is a developing country rich of cultural heritage. It has a long tradition of hydraulics technology and engineering as revealed through the presence of many remarkable ancient waterworks such as pipes, canals, tunnels, inverted siphons, aqueducts, reservoirs, cisterns, and dams (Figure 1). Based on this long tradition, Turkey is actually constructing large-scale waterworks to irrigate 8.5 million ha of land and to generate 130 billion KW/yr by means of more than 600 dams and 500 hydroelectric power plants, to promote economic development and welfare to its own people (Ozis 1996).

However, this endeavor has often been in conflict with the mission of preserving its cultural heritage and transferring them to future generations. The critical evaluation of the heritage threatened by dams in Turkey (Ozdogan 2000) shows that these issues prevent the effective management of the mentioned heritage: lack of trained personnel, the absence of a cultural inventory, bureaucracy, the effects of inundation on archaeological material, financial problems, planning ability, and politics. Especially three heritage sites-Zeugma, Hasankeyf (Kiphas/Cepha), and Allianoi (RT Ministry of Culture 2009)—have attracted special attention recently, both in national and international level, due to the three influencing dam projects; Birecik Dam, Ilisu Dam and Yortanli Dam, respectively (RT Ministry of Environment 2010). The common problem in these three cases can be basically defined as the risk of loss of the cultural heritage qualities with their exposition to the dam lakes. This situation pushes Turkey to find reasonable solutions, and it is now faced with a challenge, reconciling the conflicts between development and protection.

In this article, the studies on the protection of ancient remains of Allianoi, with regard to the reality of the Yortanli Dam near Bergama (Pergamum) in Turkey, are discussed (Figure 2). In the studied case, an archaeological heritage is threatened by a dam lake. The site has been left exposed without proper maintenance since the investigations performed between 1994 and 2006 (Figure 3). The intervention approach proposed for coping

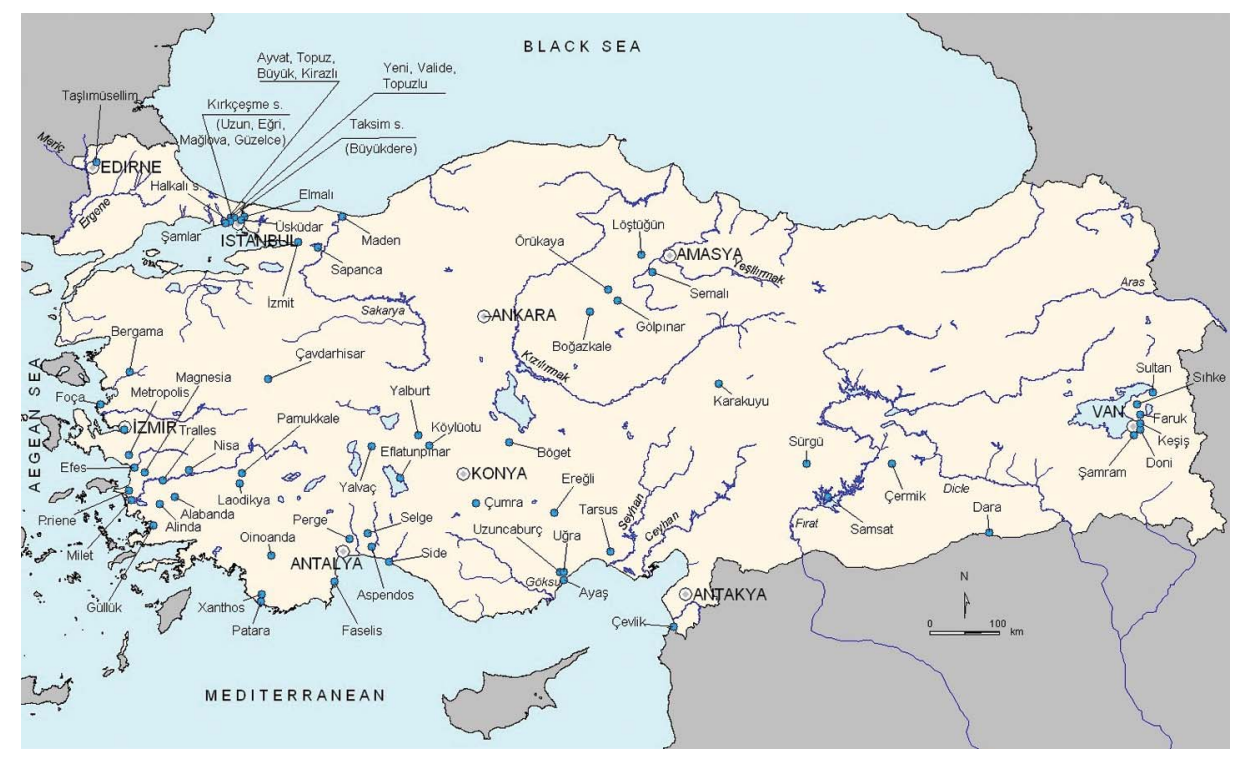

Figure 1. Map illustrating location of the Major Ancient Water Works in Anatolia (Ozis, et al. 2009) (color figure available online). 


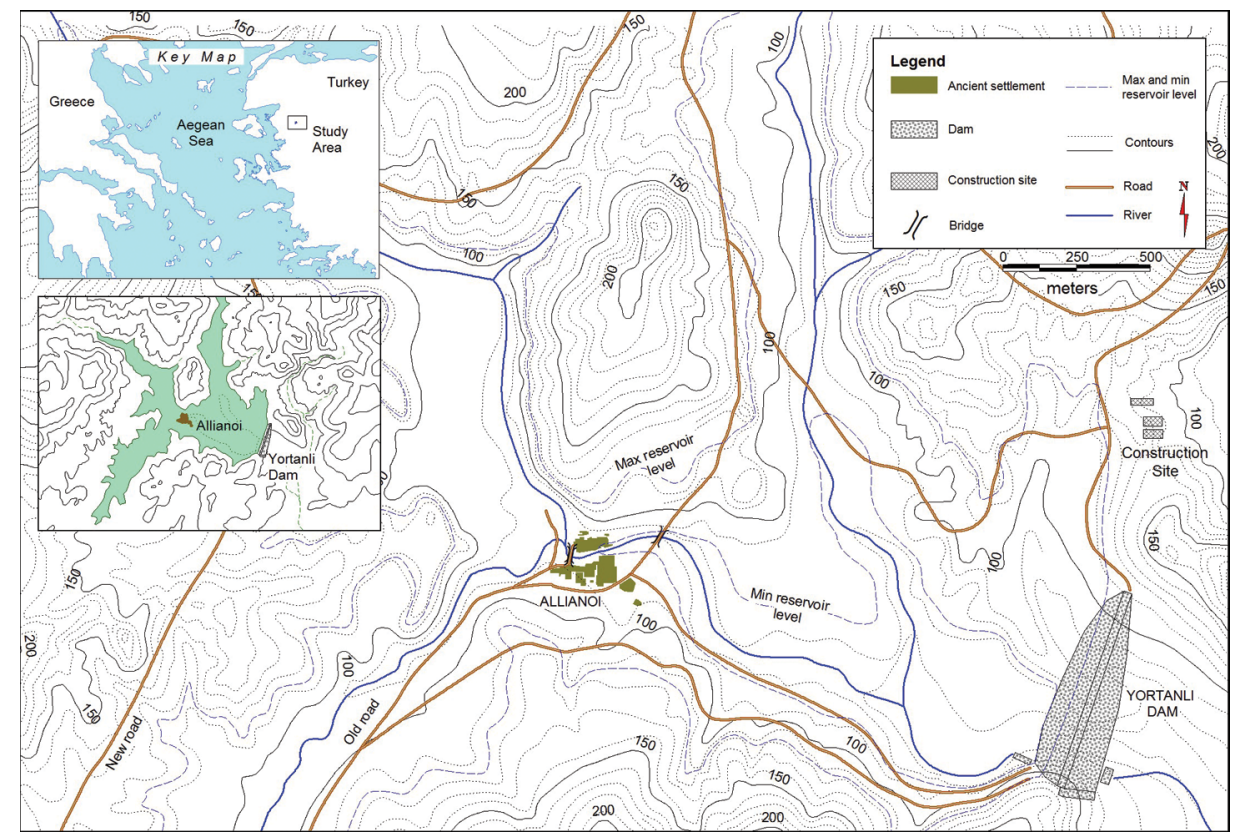

Figure 2. Map illustrating the locations of Yortanli Dam and Allianoi (IZTEK 2010, April) (color figure available online).

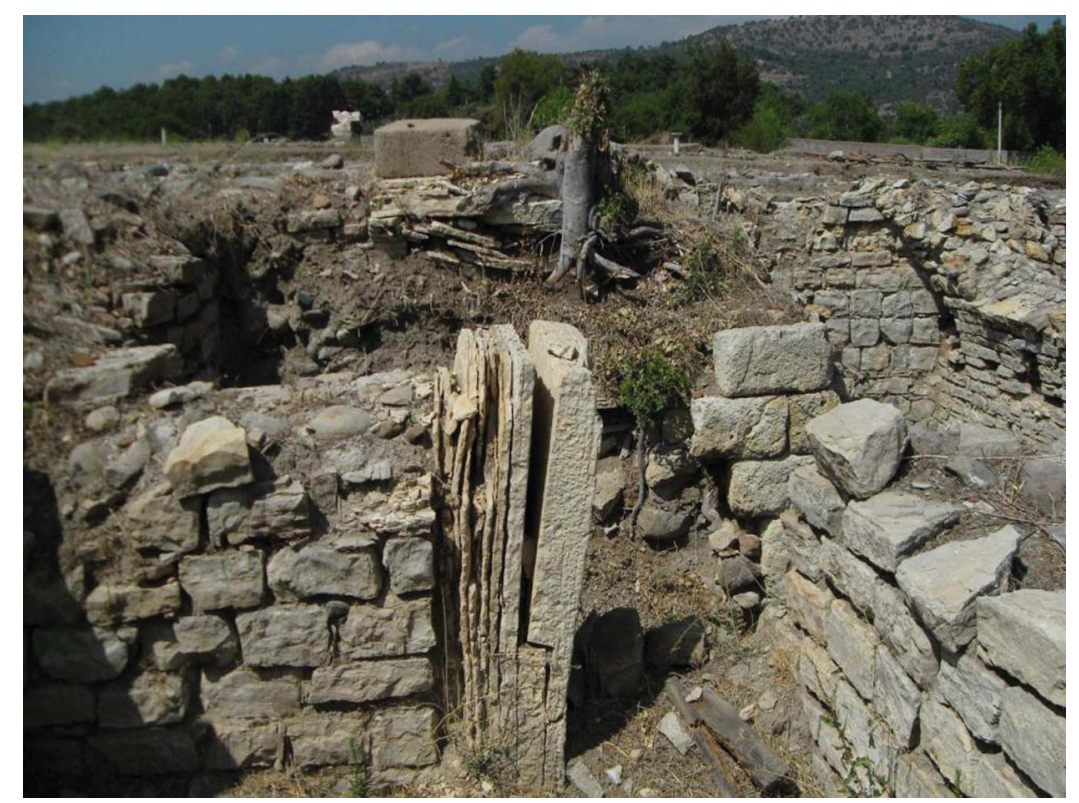

Figure 3. Photograph of conservation problems in the exposed archaeological structures (June 2010) (color figure available online). 
with this protection problem was formulated on the basis of the principle decisions taken at the international level on the preservation of archaeological heritage, recent research results on the concepts of in situ preservation and reburial in archaeological areas, and the decisions of the authorized organizations presented in the related official documents as listed in Section 2 of this article.

The principles specific for conservation and management of archaeological heritage are established in numerous international documents, taking advantage of abundant literature on the subject (Demas 2003). The international charters for the protection and management of the archaeological heritage underline the importance of in situ preservation (ICOMOS 1990; 1996). The international charters also emphasize the establishment of the appropriate conditions for protection in parallel with the archaeological investigations (ICOMOS 1990). In fact, research into the discussed problem had led to the realization that wetlands could lead to good in situ preservation (Holden et al. 2006; Douterelo et al. 2010). Consequently, the idea of deliberate reburial of archaeological remains following excavation was questioned as a feasible option. This consideration had brought the realization of the lack of information on the type of reburial environment required. Thus research is ongoing into hydrological parameters influencing in situ preservation of archaeological heritage (Holden et al. 2009). Chemical (Matthiesen 2004; Jordan 2001), physical (Björdal et al. 2000; Lillie et al. 2008) and biological (Douterelo et al. 2010; Lillie and Smith 2007) factors that will lead to the correct definition, establishment, and monitoring of environmental conditions have been studied. Nevertheless, the research results on long-term monitoring of such sites are not sufficient at present.

Within this framework, the study focuses on the decisions and implementations regarding the case of Allianoi-Yortanli and evaluates the conflicts of the process both revealed in the related documents and observed in the implementations. The aim of this study is to present legal, administrative, technical, and managerial aspects of the protection process in the case of Allianoi-Yortanli so that the monitoring and criticism of its consequences can be possible in the future.

\section{RESEARCH METHOD AND MATERIALS}

The methodology in this study is to collect and interpret the documents on the evolution of Allianoi-Yortanli discussions and the contradiction of development and protection; to evaluate the intervention decisions and implementations regarding the protection of the archaeological remains in the reservoir of Yortanli Dam; and to combine the tools of the disciplines of hydraulic engineering, structural engineering and conservation. The documents on the case of Allianoi-Yortanli are the following:

- The reports and official documents of the Turkish State Hydraulic Works (hereafter referred to as DSI) (RT Ministry of Energy 1977, 1981, 2005, 2010, 2012);

- The decisions of Izmir Number 2 Regional Board for Conservation of Cultural and Natural Assets (hereafter: Conservation Board) (RT Ministry of Culture 2001, 2008, 2010);

- The decisions of High Board for Conservation of Cultural and Natural Assets (RT Ministry of Culture and Tourism High Board 2010);

- Salvage Excavation Reports of Bergama Museum (R.T. Ministry of Culture 2001-2006);

- Scaled drawings of the archaeological site (YAY Construction, Trade, Industry and Tourism, Inc. 2008); 
- Technical reports evaluating the excavations and the protection options (Erkanal et al. 2007; Agiralioglu et al. 2007; R.T. Ministry of Culture 2008; Nuhoglu et al. 2009), where after called as the technical reports;

- The websites presenting the views of the protesting groups, either against the dam or for the dam (Allianoi web Portal 2011; Bergama Web Portal 2011);

- The conservation projects (Erturan, 2009; IZTEK 2010, April); and

- The implementation report (IZTEK 2010, December).

The case of Yortanli-Allianoi presents a protection-development dilemma with its legaladministrative, technical, and managerial aspects. Therefore, the intervention decisions and implementations are to be evaluated under these three subheadings. Considering the experience in the studied problem together with the previous research results, the evaluation of the findings is made.

\section{LEGAL-ADMINISTRATIVE ASPECTS}

The case of Allianoi-Yortanli is a matter of a process continued approximately 50 years starting from the 1960s to nowadays (Ozdemir et al. 2006). The followings are the milestones of the development history of the case. The first master plan that includes Yortanli Dam for Bakircay basin, one of the largest water basins in the entire Aegean region, was prepared in the 1963 (R.T. Ministry of Energy 1977). The initial plan of the dam was established in 1980 (R.T. Ministry of Energy 1981), the detailed application project plan was completed in 1985, and then the bidding of the project was conducted in 1993.

The local authorities of DSI, in 1994, as a routine procedure, has announced and then applied to other governmental institutions in order to take necessary steps to investigate and preserve important archeological findings in the reservoir area. Bergama Museum has conducted an excavation program under the sponsorship of DSI, accordance with the agreement between DSI and the Ministry of Culture and Tourism (R.T. Ministry of Culture and Tourism, General Directorate of Monuments \& Museums and R.T. Ministry of Energy and Natural Resources 1994). In 1994, both the construction of the dam and the first archaeological salvage excavation under the supervision of Bergama Museum was started.

Over the next 12 years, salvage excavations were continued with the collaboration and support of DSI. After a certain point, upon revealing many notable ruins, the excavation team, while working on the excavation site in one regard, started struggling against the construction of the dam by setting up Allianoi Initiative Group. Following the excavations, discussions on how the archaeological ruins were to be protected started as can be followed in the four technical reports dated July 2007, September 2007, June 2008, and May 2009 and the Conservation Project dated September 2009. Finally, a second Conservation Project unifying the recommendations of the mentioned reports and presenting the details of application defined by the decisions of the authorized organizations was prepared (IZTEK 2010, April) and approved (R.T. Ministry of Culture and Tourism, 2010).

This project, whose implementation had started in 2010 (August 23) and was completed in 2010 (November 25), defined a series of interventions for the archaeological site itself and its close by surrounding (Arisoy et al. 2011). The interventions were planned on the basis of the characteristics of the archaeological site, the dimensions of the dam reservoir, and the topographic conditions in environment and archaeological site scales. The decisions at environment scale included precautions for protecting the archaeological 


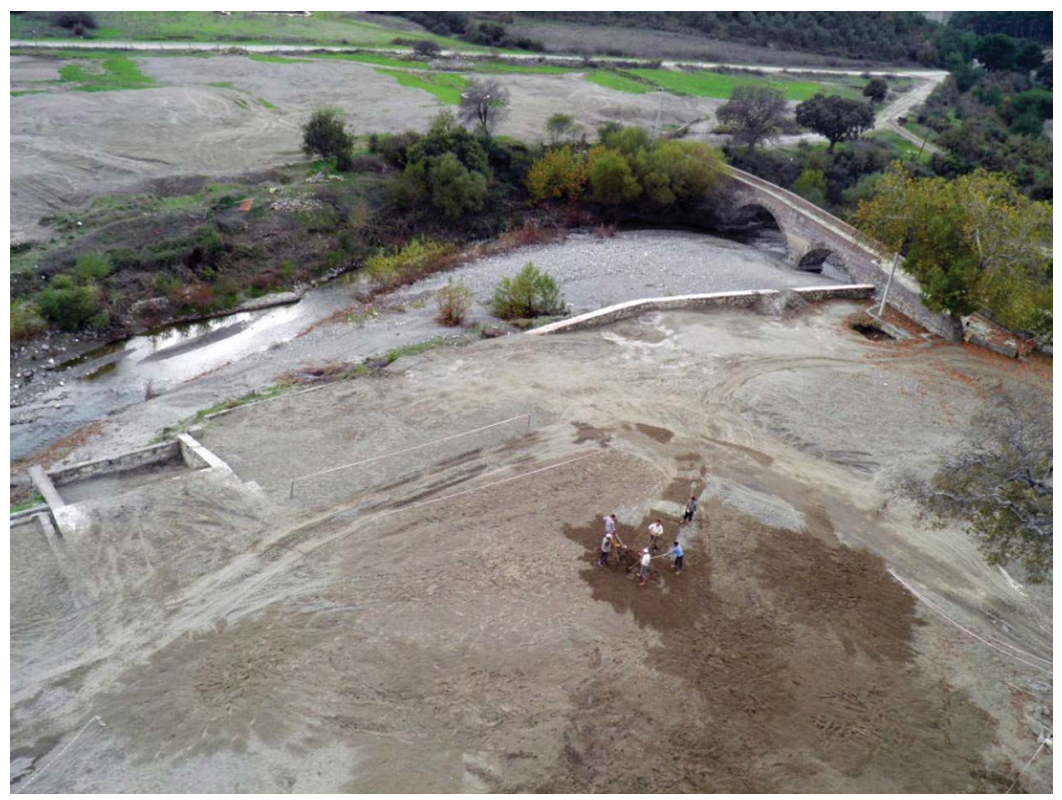

Figure 4. Photograph of Allianoi after reburial (November 2010) (color figure available online).

site against overflows at minimum water level of the dam lake. The decisions at site scale included cleaning, consolidation, and conservation interventions. The scope of the site scale implementations was the sustainability of the antique structures with minimum intervention using traditional techniques and materials as much as possible. After the implementations, pre-excavation state of the topography was established in the archaeological site of Allianoi (Figure 4). Following the retention of water in Yortanli Dam, the site will be covered totally by dam lake waters in normal conditions.

It is evaluated that the betterment of The Conservation Project (IZTEK 2010, April) could be possible with the contribution of the following points. First of all, a conservation project seeks basically solutions for the protection of a cultural heritage. Thus, it should be sponsored and controlled by authorized organizations of culture rather than those of development; in this case, DSI. As the first conservation precaution, maximum effort should be spent for avoiding the overlapping of heritage sites and dam reservoirs. The conservation project should be planned in parallel with the archaeological investigations, rather than after their completion. Simultaneous working conditions of related organizations and documentation of all implementations is a must. For example, anastylosis of some antique column pieces was made during the excavations. Its record, however, was not available in the related archives. The dismantling of the columns could not be undertaken with the anxiety of ruining their structural integrity. In turn, the third dimension introduced recently by these columns to the archaeological site gave way to an important amount of increase in the infill volume (Figure 5).

\section{TECHNICAL ASPECTS}

The characteristics of the dam and the archaeological heritage are introduced. 


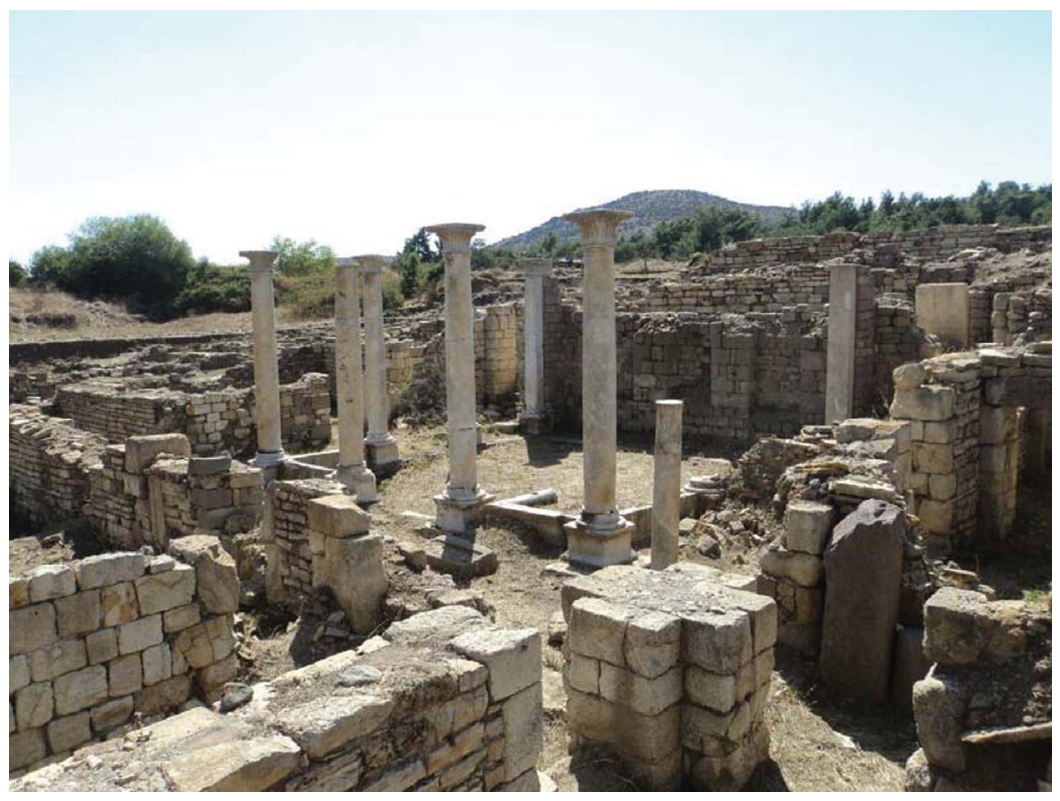

Figure 5. Photograph of columns that increased infill level (color figure available online).

\subsection{Characteristics of Yortanli Dam}

Yortanli dam was designed by DSI creating a reservoir in order to increase agricultural productivity in the region. Allianoi is in the middle of the proposed reservoir area. Yortanli Dam was constructed during 1994-2005 as an embankment dam with a height of $53 \mathrm{~m}$ above the riverbed and a crest length of approximately $700 \mathrm{~m}$ long. It stands $47 \mathrm{~m}$ high and contains 2.4 million $\mathrm{m}^{3}$ of earth and rock. The crest elevation is $117.5 \mathrm{~m}$. Normal operation level is $113 \mathrm{~m}$; the maximum water level is $115 \mathrm{~m}$ while minimum draw down level is $83.8 \mathrm{~m}$. The storage capacity at normal water level is $67.25 \mathrm{hm}^{3}$, and the reservoir surface area $4.25 \mathrm{~km}^{2}$ at the same water level. The dam has an uncontrolled side channel spillway with a crest length of $30 \mathrm{~m}$ (Figure 6). The dam would provide 37 million $\mathrm{m}^{3}$ water for irrigation of 7,793 ha of lowland for crops at Kinik. It is anticipated that the Yortanli Dam and Caltikoru Dam, which is another dam in the same river basin, would yield approximately 35.5 million USD annually (R.T. Ministry of Environment 2010; R.T. Ministry of Energy 1977; 1981).

\subsection{Characteristics of Allianoi}

Allianoi is located at the northeast area of Bergama, which is the ancient Pergamon, in Izmir province, Turkey. The ancient settlement, which is founded on the two sides of Yortanli River around Bergama-Ivrindi Road, was established originally as a health complex. There is no consensus on whether this place is Allianoi or not. Still, some government officials abstain from the use of the name, the form Allianoi (?) with a question mark is preferred in official documents.

Prior to the salvage excavations, some part of the ancient thermal baths, called Pasa Spa, had been used with some additions; however, the settlement itself was excavated 


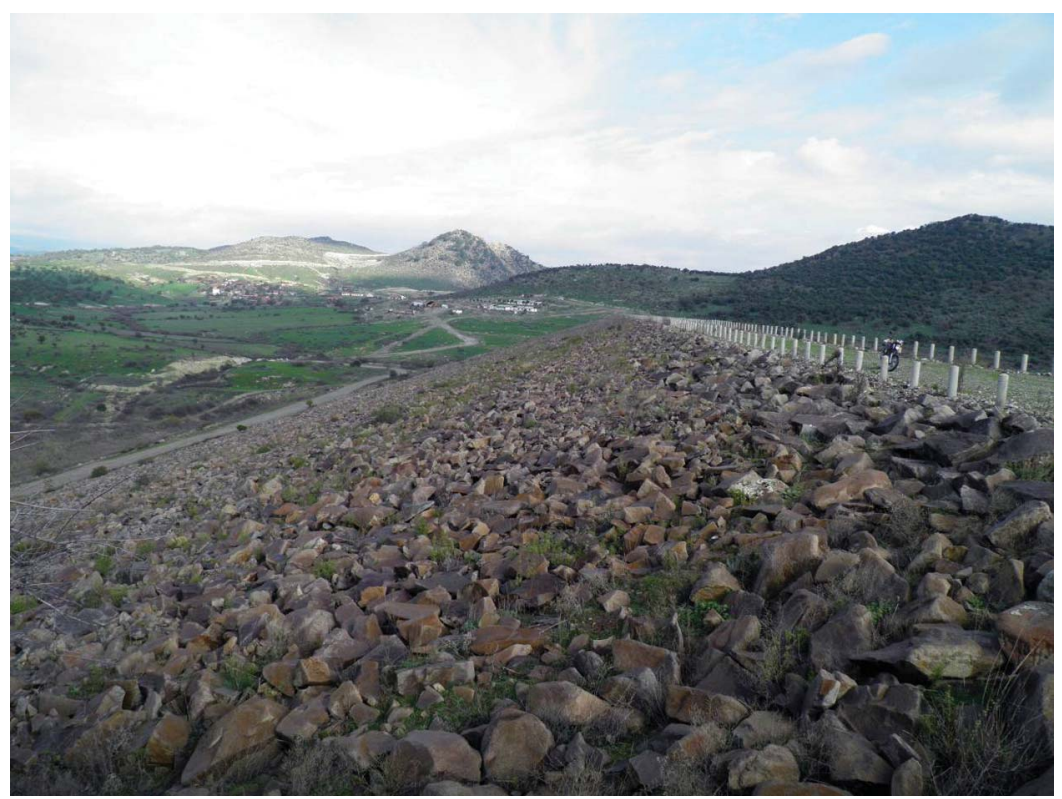

Figure 6. Photograph of Yortanli Dam viewed from the south (November 2010) (color figure available online).

parallel to the dam construction in between 1994 and 2006 (R.T. Ministry of Culture 2001-2006), and documented recently (YAY Construction, Trade, Industry and Tourism, Inc. 2008). The excavation reports state that the settlement goes back to even prehistoric period, then following Hellenistic, Roman, Byzantine, and Ottoman period. Although many archaeological artifacts referring different times were discovered, it is believed that the settlement was greatly developed during the Roman Empire period, 2nd century ad. In this period, many civil works such as streets, roads, bridges, passages, the thermal baths, and nymphaeum were built (Figure 7). The monumental thermal baths at the northern and southern coasts of Yortanli stream present the impressive characteristics of Roman termae (Norberg-Schulz 1980) with their spatial layout and elements such as halls, bays, platforms, niches, and pools. The baths are valuable not only with their spatial layout, but also with their construction technique and material usage. Although the majority of the superstructures have been demolished, the traces of vaults, domes, and arches can still be observed. The vaults and domes are out of rubble stone and lime mortar in general built in the style of masonry structures. The arches and walls are mainly out of rubble stone and lime mortar with cut stone facing. Some of these have preserved their structural integrity, while the others possess failures. The double-layered brick-lime plastering, marble wall covering on the lower parts, stone columns with capitals, the mosaic floor covering and the Nymphe sculpture now exhibited in Bergama Museum all reveal the importance given to the baths. The water system consisting of canals, pipes, and pools in relation with the baths reveals further information about the engineering techniques of the Romans. Various mass additions and ovens out of earthen-based material are contributions of the later periods that should be conserved. In addition to the mentioned archaeological heritage, historical trees, and the thermal spring are the natural assets of the settlement.

At environment scale, the collection of natural sedimentary deposits (R.T. Ministry of Energy and Natural Resources 2010) and their sieving with the aim of reforming the 


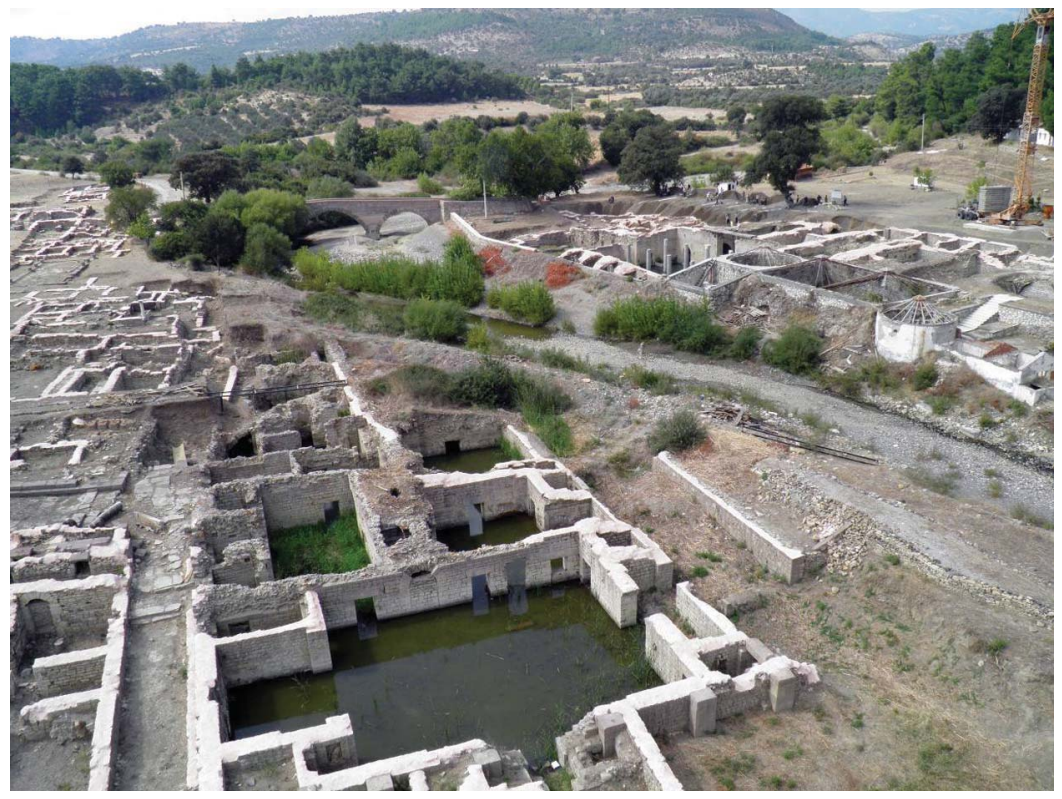

Figure 7. Photograph of Allianoi as viewed from the southeast (September 2010) (color figure available online).

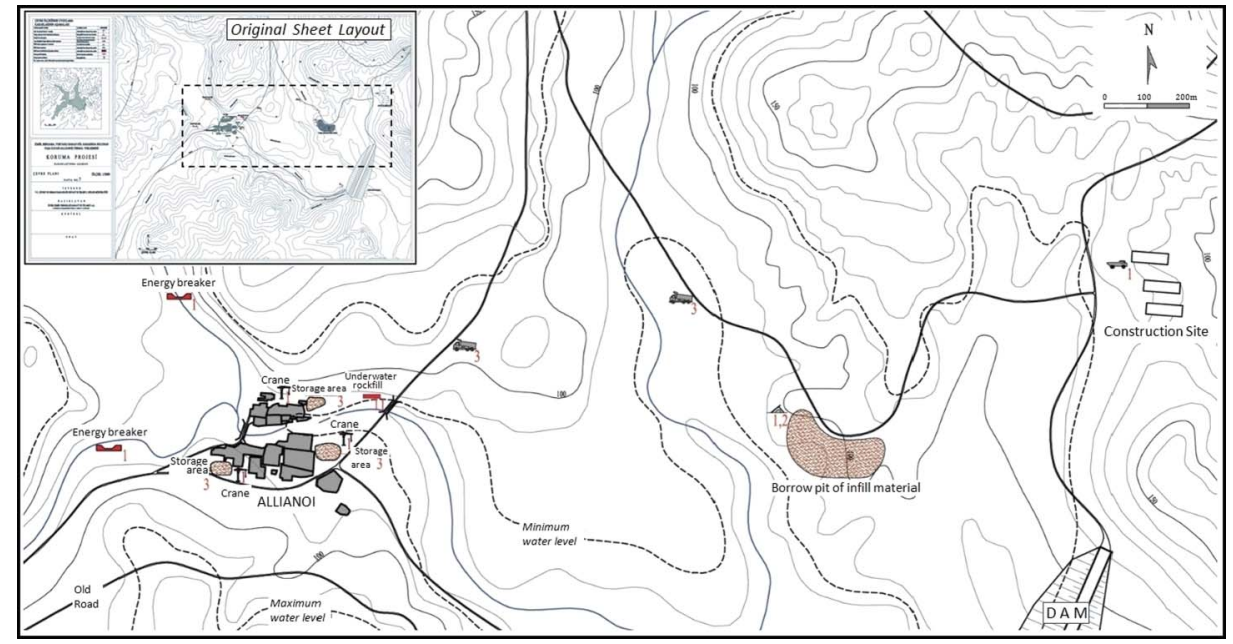

Figure 8. Map illustrating interventions at environment scale (IZTEK, April 2010) (color figure available online).

lost original infill of the archaeological site is a sustainable protection approach (Duyker 2011-2012; Batchelor 2001). The other interventions present the usage of conventional techniques experienced previously in many cases. Nevertheless, their implementation as a whole for providing a solution in the control of the environmental factors affecting the studied archaeological site is a contribution of the Allianoi-Yortanli conservation aimed implementations to the field (Figure 8).

In another regard, the applications at site scale demonstrate a parallel approach with the ones proposed in the contemporary research results or repeat the conventional technical 
manners. The cleaning of the plants with mechanical techniques by hand was the first implementation at site scale. It is a conventional technique applied in the beginning of work at archaeological sites. It made possible the observation of the excavated Allianoi as a whole and planning of the details of the implementations. In addition, the contemporary research on in situ preservation of archaeological sites without exposition to atmospheric conditions or their reburial underline the importance of plant cleaning from the view point of pH control (Matthiesen 2004) and bacteria control (Douterelo et al. 2010). These factors are considered important for achieving suitable conditions for preservation in the discussed sites.

Capping is the major consolidation intervention carried out in the studied case. It is a conventional technique applied in archaeological sites for protecting the ancient walls against climatic effects (Viles et al. 2002). In Allianoi, however, capping was preferred in order to guarantee the structural integrity of the walls whose mortars had lost their binding ability because of exposition to the atmospheric conditions without proper maintenance after the excavations. In turn, further ruining during the process of protection implementations was avoided (Figure 9). The capping provided ease in the orientation of the cranes. It will also provide reference in the future archaeological investigations.

Reburial is the major conservation intervention carried out in the studied archaeological site. The determination of appropriate preservation conditions for reburied or unexcavated archaeological sites is a recent research topic. In the case of Allianoi, the site prior to the interventions was already often moist because of the overflows of the Yortanli River passing through it (Figure 10), rises of the ground water close to the coastlines, the presence of the thermal spring, and the accumulation of rain water. In its undisturbed context, the original moist sediment protected the archaeological remains of Allianoi for centuries. The reburial environment composed of sediments collected from near-by sites may be successful in terms of the re-establishment of site characteristics similar to the pre-excavation one. In parallel with the previous research results (Björdal et al. 2000), minimum $50 \mathrm{~cm}$ thickness of infill from the top level of the ruins was preferred (IZTEK 2010,

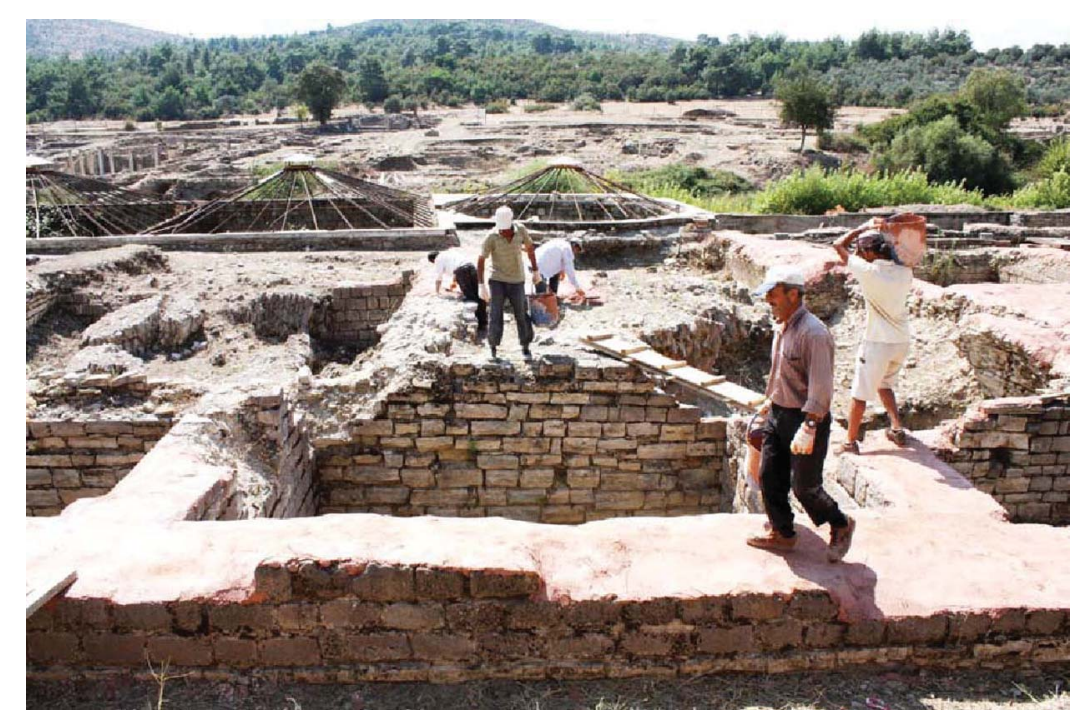

Figure 9. Photograph of capping of the ancient walls (IZTEK 2010, December) (color figure available online). 


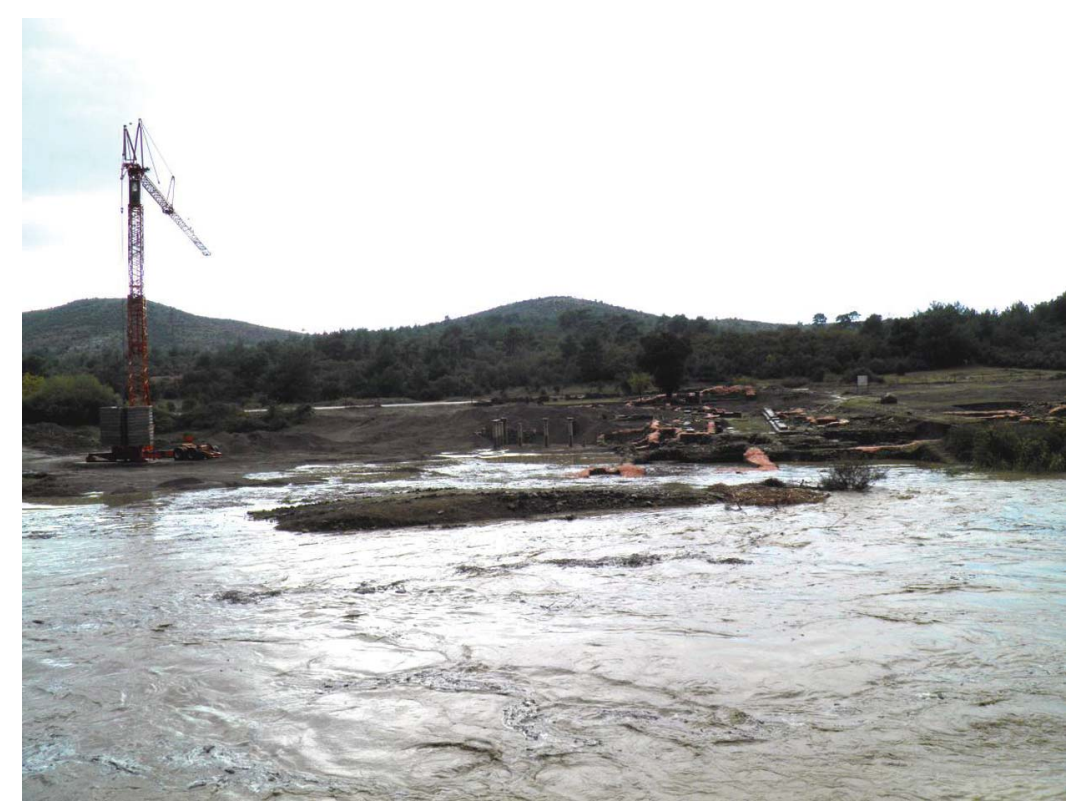

Figure 10. Photograph of Allianoi on a rainy day (October 2010) (color figure available online).

December). The $\mathrm{pH}$ value of the thermal water, which will be circulating within the infill, is 7.435 (IZTEK 2010, April). This is also close to the acceptable limits (Douterelo et al. 2010).

The ancient building materials revealed extensive deterioration requiring various interventions (R.T. Ministry of Culture 2008, June 10) in the site whole. It was observed that conservation precautions following the excavations had been insufficient. The material interventions can be discussed in three groups as stone, earth-based material, and mortar-plaster interventions.

In the archaeological sites that are decided to be exposed and presented to the visitors, the only way to preserve the external weathered layers of stone and reduce their degradation rate is consolidation. Otherwise, reburial is an effective approach to preserve the archaeological stone (Karatasios et al. 2009). Since the overall conservation policy for Allianoi was reburial, consolidation treatments to reinstate the cohesion of the weathered material were planned to be undertaken in the future investigations to be carried out after the dam completes its economic life (IZTEK 2010, December). The extensively ruined metamorphic stones, however, were decided to be supported with timber elements in order to avoid their collapse during the reburial process. Column headings, columns, pools, and detached wall covering planes all out of various types of stone including marble were wrapped with rope and fabric out of hemp (R.T. Ministry of Culture and Tourism June 10). In another regard, the stone bridge at the west, however, was not buried, since it continues serving as the route of Yortanlı stream (Figure 4). In fact, this historical bridge was repaired by Republic of Turkey, General Directorate of Highways in 1992, while its piers were further reinforced in 2010.

Earth-building materials shaped as bricks, mortars, or plasters have a long history (Goodman-Elgar 2008). Earthen buildings are vulnerable to destruction by weathering, but 
interpretation of earthen structures generally relies on analysis of construction methods encountered in well-preserved archaeological settings (Goodman-Elgar 2008). The potential usage of natural fibers and binders for stabilization of earthen-based materials is a recent research topic (Galan-Marin et al. 2010). In Allianoi, adobe mortar and fired tiles, bricks, water pipes, and jars (IZTEK 2010, December) have been exposed to weathering conditions since the excavations in 1994. Extensive decay was observed especially in adobe mortar used in the antique ovens (Figure 11). These vulnerable structural and architectural elements were first wrapped with hemp-based fabric, which was partially stabilized with hydraulic mortar, and reburied.

Characterization of ancient mortars and plasters dating from Greek times through the beginning of the 19th century reveal that they are primarily composed of lime as binder and aggregate as filler material (Budak et al. 2010).In another regard, the importance of the use of brick-lime mortars and plasters as waterproof materials in the humid or wet spaces such as those in baths has been known since the Roman period (Ugurlu and Boke 2009). Their high strength and adhesion ability in hot and humid conditions is explained by their hydraulic characters (Allen et al. 2003) due to the consciously use of porous and pozzolanic crushed bricks as aggregates in their manufacturing (Ugurlu and Boke 2009). It is known that intervention mortars and plasters used in the conservation work should have similar compositions with those of the originals in order to keep the structures sound and durable. In the conservation of the mortars and plasters of Allianoi, which was carried out in a limited extend in parallel with the related laboratory report (R.T. Ministry of Culture and Tourism 2008, June 10), commercial hydraulic lime (LaFarge natural hydraulic lime 3.5-Z, LaFarge, Bloksan, Turkey) and commercial clay (Bloksan, samut-pismil kil, no: $0-3$ ) heated approximately $800^{\circ} \mathrm{C}$ were used as pozzolanic additives in the intervention mortars and plasters. The vaults, arches, and walls suffering from mortar deterioration

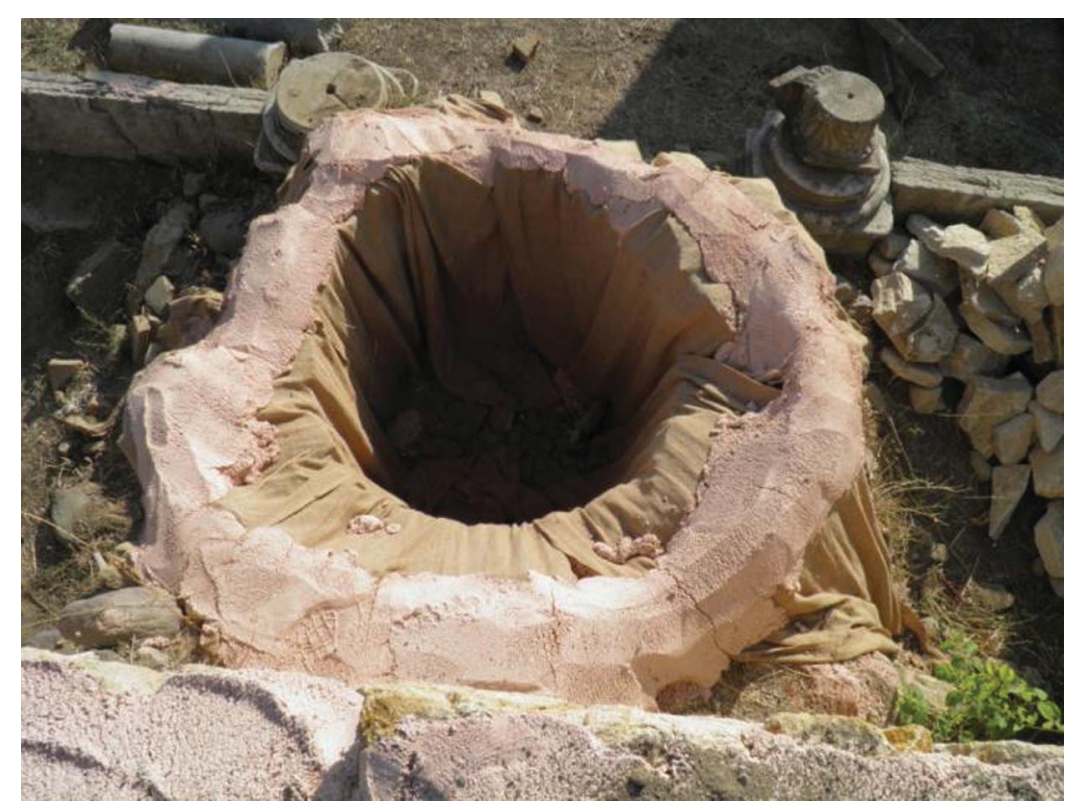

Figure 11. Photograph of oven wrapped with hemp fabric (color figure available online). 
and presenting structural risks; and the cracked and detached plaster were reinforced with grouting.

\section{MANAGERIAL ASPECTS}

The factors that played role in the management of Allianoi-Yortanli problem can be listed as the contribution of various authorized organizations, private firms and nongovernmental organizations; the work program followed in the implementations, and the organization of the construction site.

\subsection{Organizations and Firms}

The role of each organization and firm involved in the management of the discussed case is summarized in the following discussion. The Bergama Museum, which is a governmental organization in relation with the Ministry of Culture of Turkey, carried out the salvage excavations and controlled the protection implementations. Starting from the beginning of the mentioned excavations, the collaboration of a research team with the abilities of evaluating the hydrologic, archaeological, conservational, economic, and social factors of the problem as a whole would be beneficial.

DSI, which is a governmental organization in relation with the Ministry of Energy and Natural Resources of Turkey, planned the design and application process of the dam; and sponsored the excavations. Despite its governmental character, DSI has a dynamic structure and had contributed the process not only economically, but also technically. Its abilities in planning work and relatively fast implementation speed as revealed in the survey (1963), project development (1980-1985) and construction of the dam (starting in 1993) should be in harmonious with that of the archaeological investigations, which are relatively late as revealed in the survey of the archaeological site starting in 1994.

The Conservation Board, which is a governmental organization in relation with the Ministry of Culture of Turkey, took the critical decisions such as water retention in the pond, refilling of the excavation area before retention and the protection of the archaeological remains in situ, and approved the technical reports (Agiralioglu et al. 2007; Erkanal et al. 2007; R.T. Ministry of Culture, 10.06.2008; Nuhoglu et al. 2009), and the Conservation Project (IZTEK, April 2010) together with the related implementations (IZTEK, December 2010). For example, the listing decision of Allianoi as a first-degree archaeological site (R.T. Ministry of Culture and Tourism 2001, Paragraph 2, March 29) is a critical one. This decision has a statement as follows: “ . . . the site be listed as a first degree archaeological area, the antique settlement be removed outside the pond, the dam construction continue ..." Ironically, this statement has encouraged both parts and counterparts, and set off the beginning of a long new phase, consisting of many demonstrations, ongoing discussions on different platforms, law suits, and communications between related institutions (Basgelen 2008). The dam construction and the excavations (R.T. Ministry of Energy and Natural Resources 2005, October 18), the documentation studies (R.T. Ministry of Culture and Tourism 2008, December 19), evaluation of the Allianoi excavations (Erkanal et al. 2007, July 23), the discussions on the protective interventions (Agiralioglu et al. 2007), the forming of decisions for the strengthening of the ancient structures (Nuhoglu et al. 2009) and the preserving of the historical building materials (R.T. Ministry of Culture and Tourism 2008, June 10), and the conservation projects (Erturan 2009; IZTEK 2010, April) have been completed in this phase. 
Ozdemir Construction, Tourism, Energy, Industry, and Trade, Inc. (hereafter the construction firm), which is a private construction firm, constructed the dam (Ozdemir 2009) and carried out the protection implementations. The selection of experienced building masters in relation with the necessity of each implementation, and detailed explanation of each work at the site to the workers had positive impact on the quality of the end product. Nevertheless, the development of conservation anxiety for cultural heritage in its managerial personnel will improve the quality of its future work in this field.

Izmir Technology, Industry, and Trade, Inc. (hereafter IZTEK), which is a private research and development firm, designed the details of the conservation process on the basis of previously approved technical reports and decisions, and controlled the related implementations after it was held responsible by the Conservation Board (R.T. Ministry of Culture and Tourism, 2010) for this work. It prepared documents with archival value; including the implementation sheets, photograph album and report regarding the content of work. The photographs that were related with the grid system developed during the documentation of the site (Yay Construction 2008) may be useful in the three-dimensional modeling of the site prior to the future archaeological investigations. Nevertheless, IZTEK had very limited time for preparing the conservation project and completing the implementation reports due to the pressure of ongoing debates between the parts and counterparts. The team members had to travel to the construction site each workday due to their employment in other locations. Thus, establishment of consensus between parts and provision of a control team whose only job is site control is important.

The Allianoi Initiative Group is a nongovernmental organization that is set by the excavation team and protests retention of water in Yortanli Dam (Allianoi 2005-2012). It contributes to the establishment of public consciousness for conservation. Nevertheless, its actions should be planned so that their positive impact is not hindered by amateur scopes lacking technical perspective and will for supporting the aim of achieving protection-development balance.

The Chamber of Agriculture Engineers, Bergama Branch is a nongovernmental organization that supports the realization of the dam (Bergama Web Portal 2011-2012). It seems to have right in asking the reasons for the delay in irrigation of the Kinik plateau due to the irresolution of the conflicts over years.

\subsection{Work Program}

The Conservation Project defined the priority of interventions and proposed a work program (IZTEK 2010, April). The sequence of interventions, starting from the first, is detailed here:

- Organization of the construction site including the storage areas, platforms of the tower cranes, system for sieving the sand to be used in the reburial process, and circulation routes;

- Cleaning of the plants and observation of the archaeological site for further planning of the details of the implementation process;

- Strengthening of ancient structures and conservation of historical building material (includes mainly the capping of the masonry walls; and also grouting, reformation of lost mortars in the joints, supporting of vaults and arches with dry walls out of cut stone, and wrapping of delicate elements with hemp fabric); 
- Reburial of the shallow parts of the archaeological site requiring minor conservation interventions, and then the reburial of the rest; and

- Although the framework of the work program was followed in general, 57\% delay (planned work time: 8 weeks, real work time: 14 weeks) was made in the schedule because of the reasons noted in following text.

5.2.1. Problems in the Supply of Materials and Masters The Material Conservation Report (RT Ministry of Culture 2008, June 10, 2008) suggested the usage of hydraulic lime in the interventions to the antique structures. In the capping of the ruined walls, which was the major intervention in Allianoi Conservation Works, a large amount of hydraulic lime mortar was used. One-third of the compound was hydraulic lime, which is an import material. So, the problems in its supply caused some delay in the work program. Consequently, the siliceous sand, which was chosen as the infill material for the reburial of the archaeological site because of its high hydraulic conductivity and naturalness, was supplied from the near-by surroundings with ease. Nevertheless, the sieving speed of the collected natural sedimentary deposits for achieving the desired infill composition was sometimes slow compared to the infill speed. Finally, the choosiness in the selection of trained and experienced conservation masters caused some delay at the beginning of the process.

5.2.2. Problems Stemming from Weather Conditions Since the implementations were carried out in the fall, daytime was short, where as rainy and windy days were frequent (Figure 10). Especially the wetting of the infill material giving way to reduction in its flow ability was a problem. The cans of the cranes could hardly be emptied.

5.2.3. Problems Stemming from Protesting Groups Disseminating news in various public organs with limited or incorrect information, presenting implementations carried out in a legal frame as illegal, and making protest actions within the construction site gave way to an overall delay from summer to fall, created security risks for the ones working at the construction site and ruined both the technical work itself and the related tools.

\subsection{Construction Site}

Another factor that played role in the management of the problematic case is the organization of the construction site (Figure 12). Circulation of any heavy vehicle such as trucks was forbidden in the excavation area to avoid an unwanted damage. The cleaning of plants was carried out with mechanical techniques and by hand. The tower cranes and the wheelbarrows were the two major tools used for carrying the infill material. The cranes were positioned and oriented according to the deepness of the excavation areas, the minimization of the risk of overloading the ancient remains, the accessibility of the trucks carrying infill material and short term storage possibilities. Infill material was carried with wheelbarrows to the shallow areas, where as the two tower cranes were used in the deep ones. Both in the crane and in the barrow cases, sand was distributed by hand. It was compressed via wetting in the closed spaces. Hemp sacks full of siliceous sand were placed in the zones neighboring the superstructure. The pressure of finishing the work in a limited time gave way to the development of some deficiencies, such as piling of cut stone blocks close to the delicate ancient structures and invasion of pedestrian routes by vehicles. These deficiencies were minimized with the efforts of the control team. 


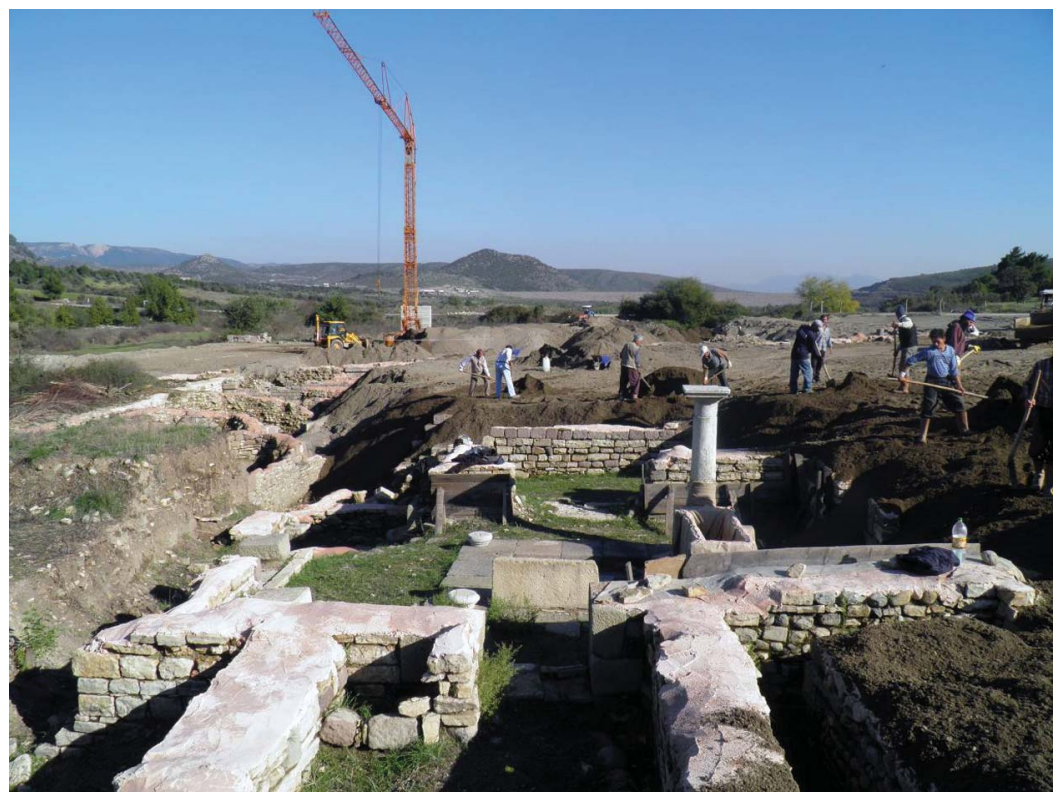

Figure 12. Photograph of construction site (October 2010) (color figure available online).

\section{CONCLUSION}

In developing countries such as Turkey, the realization of sustainable development projects that will provide economic funds while preserving heritage values is important for the establishment of a development-protection balance. However, the density and spatial distribution of historical places makes difficult to realize this mission. Ultimate protection, or the exact opposite situation, is not the case for Turkey considering that the development and the conservation of the cultural heritage are two goals that are dependant on each other. This balance necessitates the prosperous management of the conflicts as revealed in the case of the protection of Allianoi Archaeological Site located in the reservoir of Yortanli Dam. Legal, administrative, technical, and managerial aspects of the problematic case should be considered as a whole. Simultaneous collaboration of all parts and interdisciplinary work is necessary. The details of the protection process presented in this study may be useful for monitoring and evaluating its consequences with further studies. Although monitoring of the site has been attempted as proposed in the Conservation Project, it could not be realized so far because of the reserved attitude of DSI. Finally, the presentation of the intervention in the case of Allianoi-Yortanli should not be taken as an attempt for providing standard solutions, rather as an opportunity for discussing its validity within an international framework.

\section{ACKNOWLEDGEMENTS}

This article was prepared within the frame of a research project titled Investigation and Development of Protection Techniques for the Antique Thermal Settlement of Allianoi in Lake Area of Yortanli Dam and the related Applications and supported by IZTEK (Izmir Technology, Industry and Commerce Joint Stock Company) in 2010. 


\section{REFERENCES}

Agiralioglu, N., I. Ozturk, H. Gonen, T. Zeyrek, and H. Birol-Akkurt. 2007, September 14. Technical report on the implementation project for the protection of the Pasa Ilicasi in Yortanli dam lake area. Istanbul, Turkey: RT Ministry of Culture and Tourism, General Directorate of Cultural Assets and Museums, Yortanli Dam Scientific Commission.

Allen, G., J. Allen, N. Elton, M. Farey, S. Holmes, P. Livesey, and M. Radonjic. 2003. Hydraulic lime mortar for stone, brick and block masonry. Dorset, UK: Donhead, 67.

Allianoi Web Portal. 2005-2012. Allianoi. www.allianoi.org/index.php (accessed November 2, 2011).

Allianoi Web Portal. Allianoi. Available at: www.allianoi.org/index.php (accessed November 2, 2011).

Arisoy, Y., M. Hamamcioglu-Turan, A. Nuhoglu, and Y. P. Erturan. 2011. Protection of archaeological remains in Yortanli Dam Lake. In Proceedings of the 6th International Conference on Dam Engineering, eds., C. A. B. Pina, E. Portela, J. P. Gomes, J. S. Y. Tan, T. Fonsec Lisbon, Portugal, February 15-17, 2011. Lisbon, Portugal: Dam Engineering Conference, pdf 153-166.

Basgelen, N. 2008. A unique health facility from Roman period near Pergamon: Allianoi (Pasa Spa). Archaeology April-June 2008(25):129-135.

Batchelor, D. 2001. Toward a sustainable management plan: The case of Stonehenge and Avebury. In Managing change: Sustainable approaches to the conservation of the built environment, eds., J. Teutonico and F. Matero. Los Angeles, CA: Getty Conservation Institute, 95-106.

Bergama Web Portal. 2011-2012. The farmers celebrated the beginning of water retention in Yortanli Dam. http://www.bergamailcesi.com/ciftciler-yortanli-barajinin-su-tutmaya-baslamasinikutladi.html (accessed July 2, 2011).

Bergama Web Portal. The Farmers celebrated the beginning of water retention in Yortanli Dam. Available at: www.bergamailcesi.com/ciftciler-yortanli-barajinin-su-tutmaya-baslamasinikutladi.html (accessed July 2, 2011).

Björdal, C. G., G. Daniel, and T. Nilsson. 2000. Depth of burial, an important factor in controlling bacterial decay of waterlogged archaeological poles. International Biodeterioration and Biodegradation 45: 15-26.

Budak, M., S. Akkurt, and H. Boke. 2010. Evaluation of heat-treated clay for potential use in intervention mortars. Applied Clay Science 49/4: 414-419.

Demas, M. 2003. GCI Project bibliographies: Conservation and management of archaeological sites. A selected annotated bibliography. Los Angeles, CA: Getty Conservation Institute.

Douterelo, I., R. Goulder, and M. Lillie. 2010. Soil microbial community response to landmanagement and depth, related to the degradation of organic matter in English wetlands: Implications for the in situ preservation of archaeological remains. Applied Soil Ecology 44: 219-227.

Duyker, S. 2011-2012. International Scientific Committee on the Economics of Conservation. http://australia.icomos.org/get-involved/international-scientific-committees/iscec-economics-ofconservation/ (accessed February 14, 2011).

Erkanal, H., C. Ozgunel, and M. Akalin. 2007, July 23. Technical report of the evaluation commission on Allianoi excavations. Ankara, Turkey: RT Ministry of Culture and Tourism, General Directorate of Cultural Assets and Museums, Allianoi Excavations Investigation Commission.

Erturan, Y. P. 2009. September. Protection project for Izmir, Pergamum, Pasa Ilicasi Area, Allianoi(?) thermal settlement. Izmir, Turkey: RT Ministry of Energy and Natural Resources, R.T. Ministry of Energy and Natural Resources, General Directorate of State Hydraulic Works, Number II Regional Directorate.

Galan-Marin, C., C. Rivera-Gomez, and J. Petric. 2010. Clay-based composite stabilized with natural polymer and fiber. Construction and Building Materials 24: 1462-1468.

Goodman-Elgar, M. 2008. The devolution of mud brick: Ethno archaeology of abandoned earthen dwellings in the Bolivian Andes. Journal of Archaeological Science 35: 3057-3071.

Holden, J., L. J. West, A. J. Howard, E. Maxfield, I. Panter, and J. Oxley. 2006. Hydrological controls of in situ preservation of waterlogged archaeological deposits. Earth-Science Reviews 78: 59-83. 
Holden, J., A. J. Howard, L. J. West, E. Maxfield, I. Panter, and J. Oxley. 2009. A critical review of hydrological data collection for assessing preservation risk for urban waterlogged archaeology: A case study from the city of York, UK. Journal of Environmental Management 90: 3197-3204.

International Council on Monuments and Sites (ICOMOS). 1987. Charter for the conservation of historic towns and urban areas, Washington. http://www.international.icomos.org/charters/towns_e. htm (accessed February 14, 2011).

International Council on Monuments and Sites (ICOMOS). 1990. International Committee for the Management of Archaeological Heritage, Charter for the Protection and Management of Archaeological Heritage, Lausanne. http://www.international.icomos.org/ charters/arch_e.htm (accessed January 4, 2010).

International Council on Monuments and Sites (ICOMOS). 1996. Charter on the Protection and Management of Underwater Cultural Heritage, Sofia. http://www.international.icomos.org / charters/underwater_e.htm (accessed January 4, 2010).

International Council on Monuments and Sites (ICOMOS). 2010, April 6. Heritage at Risk. http:// www.international.icomos.org/risk/index.html (accessed February 14, 2011).

Izmir Technology, Industry, and Trade Inc. (IZTEK). 2010, April. Allianoi(?) Thermal Settlement in Yortanli Dam Lake area, Pasa Ilıcasi, Bergama, Izmir: Conservation project report, Izmir, Turkey: IZTEK.

Izmir Technology, Industry, and Trade Inc. (IZTEK). 2010, December. Allianoi(?) Thermal Settlement in Yortanli Dam Lake area, Pasa Ilıcası, Bergama, Izmir: Conservation implementation report, Izmir, Turkey: IZTEK.

Jordan, B. A. 2001. Site characteristics impacting the survival of historic waterlogged wood: A review. International Biodeterioration and Biodegradation 47: 47-54.

Karatasios, I., P., Theoulakis, A. Kalagri, A. Sapalidis, and V. Kilikoglou. 2009. Evaluation of consolidation treatments of marly limestones used in archaeological monuments. Construction and Building Materials 23: 2803-2812.

Lillie, M., and R. Smith. 2007. The in situ preservation of archaeological remains: Using lysimeters to assess the impacts of saturation and seasonality. Journal of Archaeological Science 34: 1494-1504.

Lillie. M., R. Smith, J. Reed, and R. Inglis. 2008. Southwest Scottish Crannogs: Using in situ studies to assess preservation in wetland archaeological contexts. Journal of Archaeological Science 35: $1886-1900$.

Matthiesen, H. 2004. In situ preservation of soil pH. Journal of Archaeological Science 31: 1373-1381.

Norberg-Sculz, C. 1980. Meaning in Western architecture. New York, NY: Rizzoli International Publications Inc., 52-53.

Nuhoglu, A., B. Arisoy, and E. Ercan. 2009, May 20. Technical report on protection of Izmir, Pergamon, Allianoi thermal settlement, structural analysis and recommendations. Izmir, Turkey: RT Ministry of Energy and Natural Resources, R.T. Ministry of Energy and Natural Resources, General Directorate of State Hydraulic, Number II Regional Directorate.

Ozdemir Construction, Tourism, Energy, Industry, and Trade Inc. 2009. Yortanli dam construction. http://www.ozdemiras.com.tr/en/project.php?id=18 (accessed November 2, 2011).

Ozdemir, Y., O. Fistikoglu, and N. Turk. 2006, May 25. R.T. Technical report prepared for the Directorate of Izmir District Number 2 Administrative Court. Izmir, Turkey: Directorate of Izmir District Number 2 Administrative Court.

Ozdogan, M. 2000. Cultural heritage and dam projects in Turkey: An overview. In Dams and cultural heritage management, Final report August 2000 (working paper submitted to the World Commission on Dams), eds. S. Brandt, and F. Hassan, World Commission on Dams Secretariat, Cape Town, South Africa, 58-61.

Ozis, U. 1996. Historical water schemes in Turkey. International Journal of Water Resources Development 12(3):347-383.

Ozis, U., O. Baykan, A. Atalay, Y. Arisoy, A. Alkan, and Y. Ozdemir. 2009. Water bridging civilizations through four millennia in Turkey. In Proceedings of the 5th World Water Forum (Istanbul 2009). Ankara, Turkey: DSI-State Hydraulic Works, 20. 
R.T. Ministry of Culture and Tourism, Directorate of Pergamum Museum. 2001-2006. Reports on salvage excavations in Yortanli dam: Allianoi. Bergama, Izmir. Izmir, Turkey: R.T. Ministry of Culture and Tourism.

R.T. Ministry of Culture and Tourism, General Directorate of Cultural Assets and Museums, Directorate of Central Laboratory for Restoration and Conservation. 2008, June 10. Technical report on protection of architectural elements of Pergamum, Allianoi thermal settlement in Yortanli dam lake area. Istanbul, Turkey: R.T. Ministry of Culture and Tourism.

R.T. Ministry of Culture and Tourism, General Directorate of Monuments \& Museums and R.T. Ministry of Energy and Natural Resources, General Directorate of Water Works. 1994, May 4. Protocol for the old assets in the Izmir-Bergama Yortanli dam lake area. Ankara, Turkey: R.T. Ministry of Culture and Tourism and and R.T. Ministry of Energy and Natural Resources.

R.T. Ministry of Culture and Tourism, Izmir Number 1 Regional Board for the Conservation of Cultural and Natural Assets. 2001, March 29. Decision numbered 9229. Izmir, Turkey: R.T. Ministry of Culture and Tourism.

R.T. Ministry of Culture and Tourism, Izmir Number 2 Regional Board for the Conservation of Cultural and Natural Assets. 2008, December 19. Decision numbered 4473. Izmir, Turkey: R.T. Ministry of Culture and Tourism.

R.T. Ministry of Culture and Tourism, Izmir Number 2 Regional Board for the Conservation of Cultural and Natural Assets. 2010, August 17. Decision numbered 6037. Izmir, Turkey: R.T. Ministry of Culture and Tourism.

R.T. Ministry of Energy and Natural Resources, General Directorate of Water Works 1977. Development report on Bakircay Basin. Izmir, Turkey: DSI 2. Bolge Yayinlari.

R.T. Ministry of Energy and Natural Resources, General Directorate of Water Works 1981. Planning report on Bakırçay-Kınık. Izmir, Turkey: DSI 2. Bolge Yayinlari.

R.T. Ministry of Energy and Natural Resources, General Directorate of Water Works, Number II Regional Directorate, Branch of Dams and HES. 2005, October 18. Official paper on excavation of old assets in Yortanlı dam lake area. No B 151 DSI 0210 00/ 718-20188. Izmir, Turkey: R.T. Ministry of Energy and Natural Resources.

R.T. Ministry of Energy and Natural Resources, General Directorate of Water Works, Number II Regional Directorate, Quality Control Laboratory. 2010, March 18. Report on characterization of infill material for Pasa Ilicasi. Izmir, Turkey: R.T. Ministry of Energy and Natural Resources.

R.T. Ministry of Energy and Natural Resources, General Directorate of Water Works, Number II Regional Directorate, Branch of Dams and HES. 2005, October 18. Report on salvage excavations for the antique remains in Yortanli dam lake area. Izmir, Turkey: R.T. Ministry of Energy and Natural Resources.

R.T. Ministry of Energy and Natural Resources, General Directorate of State Hydraulic Works (1977). Development report on Bakircay Basin. Izmir: DSI 2. Bolge Yayinlari.

R.T. Ministry of Energy and Natural Resources, General Directorate of State Hydraulic Works (1981). Planning report on Bakırçay-Kınık. Izmir: DSI 2. Bolge Yayinlari.

R.T. Ministry of Energy and Natural Resources, General Directorate of State Hydraulic Works, Number II Regional Directorate, Branch of Dams and HES (18.10.2005). Official Paper on excavation of old assets in Yortanlı dam lake area. No B 151 DSI 0210 00/ 718-20188, Izmir.

R.T. Ministry of Energy and Natural Resources, General Directorate of State Hydraulic Works, Number II Regional Directorate, Quality Control Laboratory, 2010a, March 18. Report on characterization of infill material for Pasa Ilicasi. Izmir, Turkey: R.T. Ministry of Energy and Natural Resources.

RT Ministry of Energy and Natural Resources, General Directorate of State Hydraulic Works. 2012. Works Realized during the Period of General Director Akif ÖZKALDI. http://www.dsi. gov.tr/kurumsal-yapi/yonetim/genel-mudurumuz/calismalari/2012/06/11/izmir40tesis (accessed November 26, 2012).

R.T. Ministry of Culture and Tourism, Izmir Number 1 Regional Board for the Conservation of Cultural and Natural Assets (29.03.2001). Decision numbered 9229. Izmir. 
R.T. Ministry of Culture and Tourism, Izmir Number 2 Regional Board for the Conservation of Cultural and Natural Assets (19.12.2008). Decision Numbered 4473, Izmir.

R.T. Ministry of Culture and Tourism, Izmir Number 2 Regional Board for the Conservation of Cultural and Natural Assets (17.08.2010). Decision Numbered 6037.

R.T. Ministry of Culture and Tourism High Board for Conservation of Cultural and Natural Assets (22.04.2010). Decision Numbered 765.

RT Ministry of Energy and Natural Resources, General Directorate of State Hydraulic Works, Number 16 Regional Directorate. 2012. Illsu Dam and Hydroelectric Power Station, Archaeological and Cultural Activities. http://www.ilisuprojesi.com/index.php?islem=sayfa\& say_id=75 (accessed November 26, 2012).

RT Ministry of Energy and Natural Resources, General Directorate of State Hydraulic Works. 2012. Works Realized during the Period of General Director Akif ÖZKALDI. http://www.dsi. gov.tr/kurumsal-yapi/yonetim/genel-mudurumuz/calismalari/2012/06/11/izmir40tesis (accessed November 26, 2012).

Serin, U. 2005. Threats and vulnerabilities in archaeological sites, case study: Iasos. In Proceedings of the scientific symposium monuments and sites in their setting-Conserving cultural heritage in changing townscapes and landscapes, ICOMOS. October 17-21, 2005. Xi'an, China: World Publishing Corporation.

Ugurlu, E., and H. Boke. 2009. The use of brick-lime plasters and their relevance to climatic conditions of historic bath buildings. Construction and Building Materials 23: 2442-2450.

Yay Construction, Trade, Industry and Tourism, Inc. 2008. Scaled drawings of Pasa Ilica thermal settlement, Bergama, Izmir, Turkey. Izmir, Turkey: RT Ministry of Energy and Natural Resources, R.T. Ministry of Energy and Natural Resources, General Directorate of State Hydraulic, Number II Regional Directorate.

Viles, H. A., C. Groves, and C. Wood. 2002. Soft wall capping experiments. In Stone: Stone building materials construction and associated component systems; their decay and treatment, 2, ed., J. Fidler. London, UK: James and James, 59-73. 